\title{
EVALUASI PENGELOLAAN SAMPAH SEMENTARA DAN KEPADATAN LALAT DI WARUNG MAKAN PASAR WONOKROMO SURABAYA TAHUN 2017
}

Amalia Aisyah, Rusmiati, Winarko

\begin{abstract}
ABSTRAK
Pasar merupakan salah satu tempat umum yang menghasilkan sampah. Pengelolaan sampah sangat penting untuk mencegah penularan penyakit yang salah satu penularannya melalui vector. Bila lalat hinggap di makanan yang dijual di warung makan maka kotoran yang dibawa dari sampah yang menempel di bulu atau kakinya dapat mencemari makanan yang akan di makan pengunjung atau pedagang, sehingga akan timbul penyakit. Tujuan penelitian ini adalah mengevaluasi pengelolaan sampah sementara dan kepadatan lalat di warung makan Pasar Wonokromo Surabaya tahun 2017.

Jenis penelitian ini merupakan penelitian deskriptif kualitatif. Data yang digunakan merupakan data primer hasil pengukuran dan observasi. Data sekunder diperoleh dari Pasar Wonokromo Surabaya. Objek penelitian dalam penelitian ini adalah 30 warung makan dengan kriteria indoor cooking terdapat 20 warung makan sedangkan 10 warung makan outdoor cooking.

Hasil penelitian didapatkan hasil timbulan sampah yaitu $0,21 \mathrm{~kg} / \mathrm{m}^{2}$ dan rata-rata kepadatan lalat 7 ekor/block grill. Ada 5 warung makan tingkat kepadatan lalat tinggi yaitu titik $3,5,14,15$, dan 18 . Hasil rata-rata suhu, kelembaban dan pencahayaan di warung makan adalah suhu $31^{\circ} \mathrm{C}$, kelembaban $54 \%$ dan pencahayaan 75 lux.

Kesimpulan penelitian adalah bahwa kepadatan lalat yang tinggi dipengaruhi oleh timbulan sampah yang tinggi. Saran untuk pengelola pasar yang dapat dilakukan guna mengurangi tingginya tingkat kepadatan lalat pengelola pasar perlu pengamatan terhadap tempat-tempat berkembang biaknya lalat dan apabila diperlukan dilakukan pengendalian terhadap lalat.
\end{abstract}

Kata kunci : Warung Makan, Pengelolaan Sampah, Kepadatan Lalat

\section{PENDAHULUAN}

Tempat-tempat umum merupakan tempat kegiatan bagi umum yang mempunyai tempat, sarana dan kegiatan tetap yang diselenggarakan oleh badan pemerintah, swasta, dan atau perorangan yang dipergunakan langsung oleh masyarakat (Adriyani, 2005).

Setiap aktifitas yang dilakukan oleh manusia sangat erat interaksinya dengan tempat-tempat umum, baik untuk bekerja, melakukan interaksi sosial, belajar maupun melakukan aktifitas lainnya salah satunya adalah pasar. Menurut Chandra (2007), tempat-tempat umum memiliki potensi sebagai tempat terjadinya penularan penyakit, pencemaran lingkungan ataupun gangguan kesehatan lainnya. Karena tempat umum merupakan tempat bertemunya segala macam masyarakat dengan segala penyakit yang dipunyai oleh masyarakat tersebut.

Menurut KMK No.519/ MENKES/ SK/ VI/ 2008 tentang pedoman penyelenggaraan pasar sehat bahwa status kesehatan populasi sangat ditentukan oleh kondisi tempat-tempat dimana orang banyak beraktivitas setiap harinya dan juga ketersediaan layanan kesehatan. Pasar sehat adalah kondisi pasar yang bersih, aman, nyaman, dan sehat yang terwujud melalui kerjasama seluruh stakeholder terkait dalam menyediakan bahan pangan yang aman dan bergizi bagi masyarakat. Pasar merupakan salah satu tempat umum yang menghasilkan sampah, karena pasar merupakan salah satu yang menggerakkan dinamika kehidupan ekonomi, dimana fungsinya lembaga pasar ini sebagai institusi ekonom tidak dapat terlepas dari aktivitas yang dilakukan oleh pembeli dan pedagang (Damsar, 2005).

Masalah sampah di Indonesia merupakan masalah yang rumit karena kurangnya pengertian masyarakat terhadap akibatakibat yang dapat ditimbulkan oleh sampah dan kurangnya biaya pemerintah 
untuk mengusahakan pembuangan sampah yang baik dan memenuhi syarat. Faktor lain yang menyebabkan permasalahan sampah di Indonesia semakin rumit adalah meningkatnya taraf hidup masyarakat yang tidak disertai dengan keselarasan pengetahuan tentang persampahan dan juga partisipasi masyarakat yang kurang untuk memelihara kebersihan dan membuang sampah pada tempatnya (Soemirat, 2006).

Volume sampah yang dihasilkan dari aktivitas di pasar dapat meningkat terus sehingga terjadi penumpukan sampah. Bila penumpukan sampah terus dibiarkan maka akan berpengaruh kepada daya tarik vector lalat rumah (Musca domestica) sehingga kemungkinan penularan penyakit dapat terjadi karena secara mekanis bulu-bulu badannya, kakikaki serta bagian tubuh yang lain dari lalat rumah merupakan tempat menempelnya mikroorganisme penyakit yang dapat berasal dari sampah (Nida, 2014).

Lalat dapat bertindak sebagai vektor mekanis yang menyebabkan penyakit pada manusia maupun hewan. Infeksi terjadi melalui komsumsi makanan atau minuman yang dihinggapi lalat. Peristiwa penularan penyakit yang disebarkan lalat bersumber dari makanan yang berasal dari tempat pengelolaan makanan (TPM) khususnya jasa boga, rumah makan, warung makan, dan makanan jajanan yang pengolahannya tidak memenuhi syarat kesehatan atau sanitasi lingkungan (Andriani, 2007).Tujuan penelitian ini adalah mengevaluasi pengelolaan sampah di pasar Wonokromo Surabaya terhadap kepadatan lalat.

\section{METODE PENELITIAN}

Penelitian ini termasuk jenis penelitian deskriptif untuk mengetahui pengelolaan sampah sementara dan kepadatan lalat di warung makan Pasar Wonokromo. Pendekatan yang digunakan adalah kualitatif. Objek penelitian yaitu 30 warung makan Pasar Wonokromo Surabaya dengan kriteria indoor cooking terdapat 20 warung makan sedangkan 10 warung makan outdoor cooking. Teknik pengumpulan data yang digunakan dengan pengukuran kepadatan lalat, observasi di TPS dan kuesioner kepada petugas pengelola sampah pasar di Pasar Wonokromo Surabaya. Pengolahan data dilakukan dengan cara editing untuk pengecekan dari kuesioner, kemudian ditabulasi dengan membuat tabel-tabel data sesuai dengan tujuan penelitian atau yang diinginkan oleh peneliti. Data-data yang sudah ditabulasi selanjutnya dianalisis secara deskriptif yaitu dengan analisis deksriptif pada variabel penelitian.

\section{HASIL DAN PEMBAHASAN Penilaian Pengelolaan Sampah}

Dari 30 warung makan terdapat $83 \%$ warung makan yang jaraknya dari TPS $\geq$ 10 meter dan $17 \%$ warung makan yang jaraknya dari TPS $\leq 10$ meter. Jarak TPS ke warung makan $\leq 10$ meter dapat dipastikan jumlah lalat yang akan ditemukan sangat banyak dimana mengingat TPS merupakan salah satu media atau tempat perindukan lalat.

Hasil penilaian pengelolaan sampah menunjukkan bahwa hasil dari tahap penampungan sampah sebesar $85,7 \%$ termasuk kategori baik karena tempat penampungan sampah yang digunakan kuat, kedap air, tahan karat dan mudah dibersihkan.

Hasil penilaian pengelolaan sampah menunjukkan bahwa hasil dari tahap pembuangan sampah sementara sebesar $75 \%$ termasuk kategori kurang karena TPS berjarak kurang dari 10 meter dari bangunan pasar dan masih menjadi tempat perindukan vector seperti lalat.

Hasil penilaian pengelolaan sampah menunjukkan bahwa hasil dari tahap pengangkutan sebesar $100 \%$ termasuk kategori baik karena sampah diangkut ke TPA 1 kali sehari dan sudah memiliki alat pengangkut sampah sendiri alat pengangkut sampah yang digunakan kuat dan mudah dibersihkan. 


\section{Penilaian Petugas TPS}

Dari 5 petugas pengelola sampah didapatkan hasil bahwa $100 \%$ petugas pengelola sampah mempunyai pengetahuan baik. Pengetahuan yang dimaksud adalah kemampuan petugas dalam memahami sampah dan pengelolaannya.

Didapatkan bahwa 80\% APD (Alat Pelindung Diri) petugas pengelola sampah kategori kurang karena petugas tidak memakai perlengkapan yang lengkap seperti tidak memakai sarung tangan, topi, sepatu boots dan tidak memakai pakaian kerja sewaktu bekerja petugas hanya memakai masker.

\section{Rata-rata Pengukuran Kepadatan Lalat Hasil rata-rata pengukuran kepadatan lalat pada fly grill yaitu sebesar 7 (ekor/blok grill) termasuk dalam kategori tinggi. Ada 5 warung makan kepadatan lalat dalam kategori tinggi yaitu titik 3, 5, 14, 15 dan 18. Hal ini disebabkan karena jarak yang dekat dengan TPS dan warung makan sehingga sampah ini dapat menyebabkan lalat. Hal inilah yang membuat lalat lebih banyak dari pada titik lain.}

TABEL 1

HASIL RATA-RATA SUHU, KELEMBABAN, PENCAHAYAAN, TIMBULAN SAMPAH DAN KEPADATAN LALAT PASAR WONOKROMO SURABAYA TAHUN 2017

\begin{tabular}{|c|c|c|c|c|c|}
\hline $\begin{array}{l}\text { Titik / } \\
\text { Tempat }\end{array}$ & $\begin{array}{c}\text { Timbulan } \\
\text { Sampah } \\
\left(\mathrm{kg} / \mathrm{m}^{2}\right)\end{array}$ & $\begin{array}{c}\text { Kepadatan } \\
\text { Lalat } \\
\text { (ekor/block } \\
\text { grill) }\end{array}$ & $\begin{array}{l}\text { Suhu } \\
\left({ }^{\circ} \mathrm{C}\right)\end{array}$ & $\begin{array}{c}\text { Kelembaban } \\
(\%)\end{array}$ & $\begin{array}{c}\text { Pencahayaan } \\
\text { (Lux) }\end{array}$ \\
\hline 1 & 0,085 & 5 & 31 & 57 & 71 \\
\hline 2 & 0,105 & 7 & 30 & 55 & 74 \\
\hline 3 & 0,35 & 8 & 30 & 57 & 71 \\
\hline 4 & 0,05 & 5 & 31 & 53 & 78 \\
\hline 5 & 0,45 & 9 & 31 & 52 & 72 \\
\hline 6 & 0,205 & 7 & 31 & 52 & 74 \\
\hline 7 & 0,15 & 6 & 31 & 55 & 74 \\
\hline 8 & 0,095 & 5 & 32 & 59 & 83 \\
\hline 9 & 0,225 & 7 & 32 & 49 & 75 \\
\hline 10 & 0,21 & 7 & 31 & 53 & 72 \\
\hline 11 & 0,09 & 4 & 33 & 47 & 75 \\
\hline 12 & 0,25 & 6 & 34 & 44 & 72 \\
\hline 13 & 0,15 & 7 & 33 & 49 & 72 \\
\hline 14 & 0,4 & 8 & 30 & 66 & 86 \\
\hline 15 & 0,3 & 8 & 35 & 58 & 75 \\
\hline 16 & 0,1 & 6 & 31 & 42 & 77 \\
\hline 17 & 0,2 & 6 & 31 & 56 & 75 \\
\hline 18 & 0,3 & 8 & 31 & 55 & 78 \\
\hline 19 & 0,3 & 7 & 30 & 64 & 78 \\
\hline 20 & 0,2 & 7 & 31 & 55 & 75 \\
\hline Jumlah & 4,215 & 133 & 629 & 1078 & 1507 \\
\hline Rata-rata & 0,21 & 7 & 31 & 54 & 75 \\
\hline
\end{tabular}


Hasil pengukuran rata-rata timbulan sampah di 20 penampungan sampah warung makan indoor cooking didapatkan hasil $0,21 \mathrm{~kg} / \mathrm{m}^{2}$ dengan kepadatan lalat 7 ekor/block grill termasuk dalam kategori tinggi. Suhu, kelembaban dan pencahayaan didapatkan hasil rata-rata suhu $31^{\circ} \mathrm{C}$, kelembaban $54 \%$, pencahayaan 75 lux.

\section{Evaluasi Pengelolaan Sampah Sementara dan Kepadatan Lalat}

Hasil pengukuran dari 20 warung makan indoor cooking didapatkan hasil 5 titik rata-rata tertinggi yaitu titik 3 (warung makan nasi pecel), titik 5 (warung makan nasi campur), titik 14 (warung makan nasi pecel), titik 15 (warung makan nasi goreng), dan titik 18 (warung makan penjual soto). Kepadatan lalatnya tinggi karena dipengaruhi oleh timbulan sampah yang tinggi. Kepadatan lalat dikategorikan tinggi karena dipengaruhi oleh faktor suhu, kelembaban dan pencahayaan. Dari 5 titik tertinggi didapatkan hasil jarak warung makan dengan TPS $\leq 10$ meter sehingga membuat kepadatan lalat tinggi.

\section{Kesimpulan}

1. Hasil rata-rata timbulan sampah di tempat penampungan sampah warung makan adalah $0,21 \mathrm{~kg} / \mathrm{m}^{2}$ per hari.

2. Pengukuran jarak didapatkan hasil dari 30 warung makan terdapat $83 \%$ warung makan yang jaraknya dari TPS $\geq 10 \mathrm{~m}$ dan $17 \%$ warung makan yang jaraknya dari TPS $\leq 10$ meter.

3. Pengelolaan sampah tahap penampungan dikategorikan baik dengan prosentase $85,7 \%$, tahap pembuangan sampah sementara dikategorikan kurang dengan prosentase $75 \%$, tahap pengangkutan dikategorikan baik dengan prosentase $100 \%$.

4. Pengetahuan petugas pengelola sampah dikategorikan baik dengan prosentase $100 \%$

5. Hasil pengukuran kepadatan lalat pada fly grill dengan hasil rata-rata sebesar 7 ekor/block grill termasuk dalam kategori tinggi
6. Hasil pengukuran suhu, kelembaban dan pencahayaan diperoleh hasil rata-rata yaitu suhu $31{ }^{\circ} \mathrm{C}$, kelembaban $54 \%$ dan pencahayaan 75 lux.

7. Kepadatan lalat yang tinggi dipengaruhi oleh timbulan sampah yang tinggi.

\section{Saran}

1. Bagi Instansi Pasar

Perlunya pengamatan terhadap tempat-tempat berkembang biaknya lalat dan apabila diperlukan dilakukan pengendalian terhadap lalat.

2. Bagi Pedagang

Warung makan yang menyajikan makanan atau minuman sebaiknya menggunakan penutup makanan atau minuman supaya lalat tidak hinggap. Dan membuang sampah pada tempatnya.

3. Bagi Peneliti Lain

Hasil penelitian ini dapat dijadikan sebagai data atau informasi dasar untuk melakukan penelitian dengan variabel-variabel lain dan metode penelitian yang berbeda

\section{DAFTAR PUSTAKA}

Chandra, Budiman. 2007. Pengantar Kesehatan Lingkungan. Jakarta: EGC

Damanhuri, Erni dan Tri Padmi, 2010. Diktat Kuliah Pengelolaan Sampah. Bandung: Institut Teknologi Bandung.

Damsar, 2005. Sosiologi Pasar. Padang: Laboratorium Sosiologi Fisip Universitas Andalas.

Keputusan Menteri Kesehatan No. 519/MENKES/SK/VI/2008 Tentang Pedoman Penyelenggaraan Pasar Sehat. Undang-Undang Nomor 18 Tahun 2008 Tentang Pengelolaan Sampah. 